\title{
Clinical Effectiveness of $4 \%$ tetrasodium EDTA as a routine non-antibiotic antimicrobial lock solution in central venous access devices of hemodialysis and TPN patients against the
}

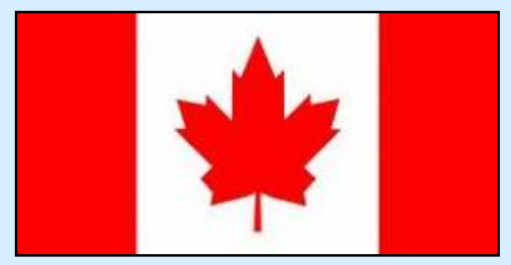

TripleThreat ${ }^{\mathrm{TM}}$ : An 18-month Canadian experience.

${ }^{1}$ SterileCare Inc, 15 Allstate Parkway, Suite 600, Markham, Ontario Canada; ${ }^{2}$ Providence Health Centre, St-Paul's Hospital, Vancouver, British Columbia Canada

\section{BACKGROUND INFORMATION}

The ideal catheter lock solution should be able to prevent the occurrence of the TripleThreat ${ }^{\mathrm{TM}}$ of clot, bacterial colonisation and biofilm formation. Providing an effective barrier for the inside of central venous access devices (CVADs) must be part of the multimodal approach to decrease the risk of catheter related complications such as catheter related bloodstream infections (CRBSI) and occlusions. However, this lock solution should be effective at knocking out all three interrelated threats (see figure above). The in vitro effectiveness of a novel nonantibiotic antimicrobial solution of $4 \%$ tetrasodium EDTA (T-EDTA) was confirmed against biofilms formed by clinically relevant bacteria and fungi. The anticoagulant property of EDTA is well known and trusted.

\section{OBJECTIVE}

The objective of this study was to collect post approval safety and efficacy data from the use of an approved 4\% T-EDTA lock solution in Canadian patients compared to the current standard of care in hemodialysis and total parenteral nutrition (TPN) patients.

\section{MATERIALS AND METHODS}

Hemodialysis and TPN patients with CVADs were selected across Canada according to their high risk of CRBSI and alteplase (r-TPA) use. This criteria was necessary to show whether a difference in these clinical endpoints would make a significant clinical and economical impact on the patient and for hospitals in a short period of time. A Return on Investment (ROI) model previously validated by a third party expert was used to show the financial impact of using the Canadian approved 4\% T-EDTA solution (KiteLock 4\% Sterile Catheter Lock Solution) versus the current standard of care. Before and during data were collected by study nurses.

TABLE 3 - Return on Investment (ROI) example for TPN patients - A Financial Case for Change
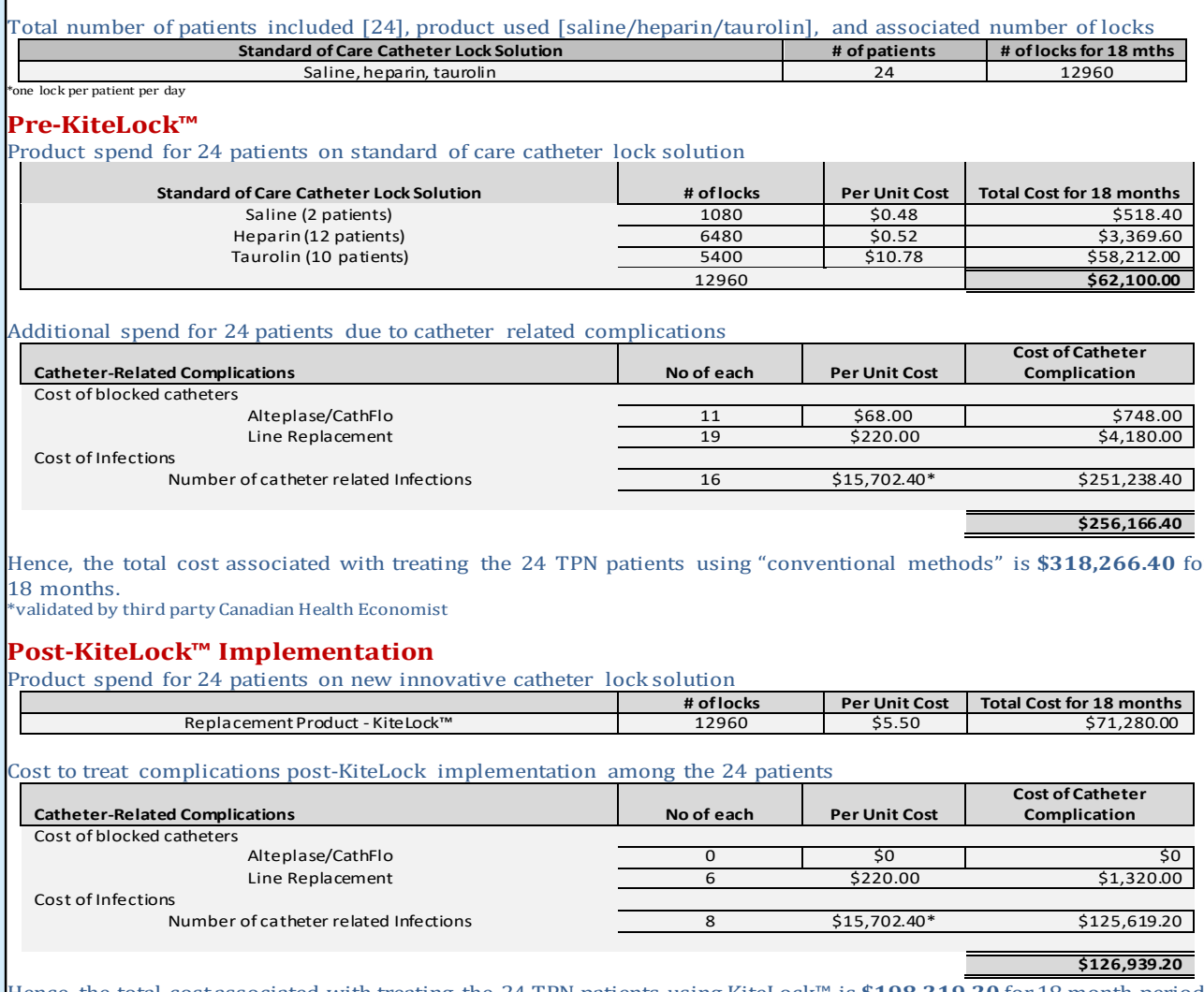

On Investment for Organizatio

\begin{tabular}{|l} 
Expenditure per month for standard/current catheter \\
\hline Savings per month Post Kite-Lock Implementation \\
\hline Number of Months to achieve a Return on Investment \\
\hline
\end{tabular}
Lainesse $\mathbf{C}^{1}$, Kelln $\mathrm{K}^{1}$ and Hill $\mathrm{J}^{2}$.

\section{RESULTS}

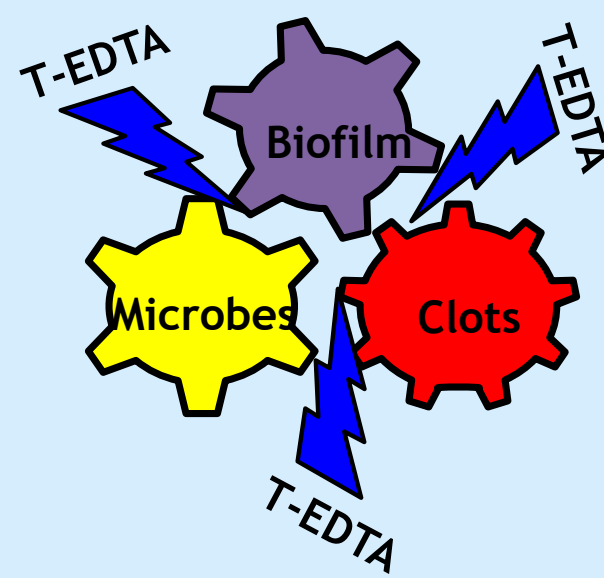

Canadian data collected over the last 18 months show both a clinically relevant decrease in CRBSI and alteplase use when the standard catheter lock solution (4\% sodium citrate for hemodialysis (Table 1); taurolidine, heparin and saline for TPN patients (Table 2)) was replaced by $4 \%$ T-EDTA. The most frequent use of this lock solution was once a day in TPN patients with no safety concerns. Hypocalcemia or bleeding episodes were not observed with its use over time. ROI was positive for all hospitals. Table $\mathbf{3}$ is an example of a Financial Case for Change.

\begin{tabular}{|c|c|c|c|c|c|c|c|c|c|c|}
\hline Hospital/Centre & Province & Start date & $\begin{array}{c}\text { Patient } \\
\text { population }\end{array}$ & $\begin{array}{c}\begin{array}{c}\text { Number of } \\
\text { patients }\end{array} \\
.\end{array}$ & $\begin{array}{l}\text { Duration of } \\
\text { evaluation } \\
\text { (weeks) }\end{array}$ & $\begin{array}{c}\text { Percent } \\
\text { reduction in } \\
\text { alteplase doses }\end{array}$ & $\begin{array}{c}\text { Percent } \\
\text { reduction in } \\
\text { CLABSIs }\end{array}$ & $\begin{array}{c}\text { ROI } \\
\text { (savings in CAD) }\end{array}$ & Testimonials clinicians & Adverse reaction \\
\hline Sault Area Hospital & on & Jun-17 & Hemodialysis & 5 & 12 & 71 & NA & $\begin{array}{c}\$ 2,925^{*} \\
\text { in } 3 \text { months }\end{array}$ & $\begin{array}{c}\text { Patients are doing very well, putting more } \\
\text { patients on as we follow the new medical } \\
\text { directive }\end{array}$ & None reported \\
\hline $\begin{array}{l}\text { St-loseph Health } \\
\text { Centre }\end{array}$ & ON & Sep-17 & Hemodialysis & 19 & 20 & 52 & 100 & $\begin{array}{c}\$ 52,192 \\
\text { in } 5 \text { months }\end{array}$ & $\begin{array}{c}\text { Patients will revert to the standard of care } \\
\text { and data will be collected to compare } \\
\text { effectiveness and ROI }\end{array}$ & $\begin{array}{l}\text { metallic taste, "milky lines } \\
\text { in } 9 \text { out of } 19 \text { patients }\end{array}$ \\
\hline $\begin{array}{l}\text { St Johns Regional } \\
\text { Health Centre }\end{array}$ & NB & Nov-17 & Hemodialysis & 30 & 12 & 41 & NA & $\begin{array}{l}\$ 9,762^{*} \\
\text { in } 3 \text { months }\end{array}$ & $\begin{array}{c}\text { 3-month trial with Kitelock reported a } 47 \% \\
\text { reduction in alteplase use }\end{array}$ & none reported \\
\hline $\begin{array}{l}\text { Hôpital } \\
\text { Maisonneuve- } \\
\text { Rosemont }\end{array}$ & Qc & Feb-18 & Hemodialysis & 11 & 12 & ongoing & ongoing & ongoing & $\begin{array}{l}\text { little alteplase has been used compared to } \\
\text { before Kitelock; catheters seem to work } \\
\text { more efficiently }\end{array}$ & none reported \\
\hline
\end{tabular}

\begin{tabular}{|c|c|c|c|c|c|c|c|c|}
\hline Hosp & Prov & Start date & $\begin{array}{c}\text { No of } \\
\text { patients }\end{array}$ & \begin{tabular}{|l} 
Duration of \\
evaluation \\
(weeks)
\end{tabular} & $\begin{array}{c}\text { Percent } \\
\text { reduction in } \\
\text { alteplase } \\
\text { doses }\end{array}$ & $\begin{array}{l}\text { Percent } \\
\text { reduction in } \\
\text { CLABSIs }\end{array}$ & Testimonials clinicians & Adverse reaction \\
\hline $\begin{array}{l}\text { St-Paul's Providence } \\
\text { Health Centre }\end{array}$ & BC & 16-oct & 24 & 72 & 100 & 50 & $\begin{array}{l}\text { Patients are able to aspirate better and the catheter feels } \\
\text { similar to the first day it was inserted }\end{array}$ & transient metallic taste; transient tingling of lips \\
\hline $\begin{array}{l}\text { Fraser Valley Health } \\
\text { Centre }\end{array}$ & BC & 16-oct & 2 & 72 & unknown & none reported & $\begin{array}{l}\text { All is going well with Magnesium patient with an IVAD (new } \\
\text { from November) who is on Kitelock 2x/week; delivery system } \\
\text { and volume is a bit inconvenient }\end{array}$ & None reported \\
\hline \begin{tabular}{|l} 
Ottawa General \\
Hospital - TPN
\end{tabular} & ON & 16-oct & 3 & 12 & unknown & unknown & No comments at this time & Infection episode in patient rationing lock solution \\
\hline Foothills Hospital & AB & 17-Mar & 1 & 56 & 1 used & 1experienced & $\begin{array}{c}\text { Difficult to say given we only have one patient on, with one } \\
\text { years experience. During that time she has had one bacteremia } \\
\text { for enterococccus faecalis; It adds additional steps to their } \\
\text { procedures which they are self managing. Design of ampule } \\
\text { challenging. Has to use pliers to remove top. It has not been } \\
\text { totally effective (i.e. one occlusion and one bacteremia while } \\
\text { on therapy) }\end{array}$ & None reported \\
\hline $\begin{array}{l}\text { Toronto Children's } \\
\text { Hospital* }\end{array}$ & ON & 17-Sep & 20 & 28 & ongoing & 100 & going well, convincing evidence & Anemia due to aspiration of the lock \\
\hline London TPN & ON & $\mid \begin{array}{c}\text { October } \\
2017(1) ; \\
\text { November } \\
\text { 2017(2); } \\
\text { December } \\
2017(1)\end{array}$ & 4 & 16-24 weeks & 100 & 100 & $\begin{array}{l}\text { so far, no infections, and no TPA required as of yet on these } \\
\text { patients but only been } 4-6 \text { months, but some of these patients } \\
\text { had frequent infections(every other month); Required some } \\
\text { teaching, but minimal as these patients are independent in } \\
\text { their line access/fllushing, but now draw discard...also, had a lot } \\
\text { of issues with community care access getting approval on each } \\
\text { patient and coordinating with provider }\end{array}$ & None reported \\
\hline \begin{tabular}{|l} 
Queen Elizabeth I \\
Hospital \\
\end{tabular} & PEI & & & & ongoing & ongoing & No comments at this time & None reported \\
\hline $\mid$\begin{tabular}{|l} 
McMaster \\
Childrens's hospital*
\end{tabular} & on & $\mid \begin{array}{l}\text { 2018-01-01; } \\
\text { March 2018 }\end{array}$ & 6 & 4-12 weeks & 1 used & 1 infection & $\begin{array}{l}\text { Hope that infections would be reduced while on Kitelock; main } \\
\text { disadvantage: Withdrawal of blood daily (hoping that the } \\
\text { subsequent dose of Kitelock will clear any fibrin left from daily } \\
\text { withdrawal of blood). }\end{array}$ & \begin{tabular}{|l} 
Line had become more stiff to flush and needed one dose \\
of cath-flo after using Kitelock for several weeks (not \\
sure if it is related to home nurse flushing and perhaps \\
not doing as turbulent a flush or if related to Kitelock)- \\
since cath-flo, no further isssues.
\end{tabular} \\
\hline $\mid \begin{array}{l}\text { St-Michael's } \\
\text { Hospital }\end{array}$ & ON & 17-Sep & 3 & 24 & 100 & 100 & patients have not been admitted for line infection since starting & $\begin{array}{c}\text { a few patients thought they were having reactions, } \\
\text { seemed nervous to use, difficult initially to get LIHN to } \\
\text { pay for it, requires more teaching for administration than } \\
\text { Hepalean as llHN staff not familiar yet }\end{array}$ \\
\hline $\begin{array}{l}\text { University Health } \\
\text { Network }\end{array}$ & ON & 18-Mar & 30 & 6 & ongoing & ongoing & No comments at this time & None reported \\
\hline
\end{tabular}

\section{DISCUSSION AND CONCLUSIONS}

* Results highlight the ability of 4\% T-EDTA to clinically reduce bacterial burden and biofilms in CVADs as well as providing well-established anticoagulant activities.

* Results also show a positive ROI for Canadian hospitals with the use of the approved catheter lock solution.

* Patients at high risk benefit from catheter maintenance and salvage with the use of $4 \% \mathrm{~T}$ EDTA as the sole lock solution.

* Conversion of hospitals (low and high risk patients) is in progress to address benefits of both prevention and treatment.

\section{REFERENCES}

Pittiruti et al, 2016. Evidence-based criteria for the choice and the clinical use of the most appropriate lock solutions for central venous catheters (excluding dialysis catheters): a GAVeCeLT consensus. J Vasc Access, 17(6):453-464.

Kanaa, $M$ et al, 2015. Cathasept line lock and microbial colonization of tunneled hemodialysis catheters: A multicenter randomized controlled trial. Am J Kidney Dis, 66(6):1015-1023.

Percival SL et al, 2005. Tetrasodium EDTA as a novel central venous catheter locking solution against biofilm. Infection Control and Hospital Epidemiology,26(6):515-519.

Kite $\mathrm{P}$ et al, 2004. Use of in vivo-generated biofilms from hemodialysis catheters to test the efficacy of a novel antimicrobial catheter lock for biofilm eradication in vitro. Journal of Clinical Microbiology, 42(7):3073-3076. 